\title{
Inovasi Kemasan dan Perluasan Pemasaran Usaha Rempeyek di Yogyakarta
}

\author{
Siska Candra Ningsih*1, Kintoko², Puji Handayani Putri ${ }^{3}$ \\ 1,2Program Studi Pendidikan Matematika, ${ }^{3}$ Program Studi Teknik Informatika, Universitas PGRI \\ Yogyakarta \\ e-mail: $\underline{\text { siska@upy.ac.id }}^{1}$, kintlazarony@gmail.com $^{2}$, pujihp@upy.ac.id $^{3}$
}

\begin{abstract}
The business group of Peyek $3 E$ is a home industry business which is managed in a simple by a group of housewives in downtown of Yogyakarta. The business is run to improve the family's economy. Peyek is produced and packaged simply with simple tools so that it is oily and packaged in a simple way. The Peyek $3 E$ business group is assisted to improve the quality of its production and expand marketing. This activity goes through 4 steps, namely preparation, implementation, evaluation, and reporting. The results of service activities can be seen from the production aspect and marketing aspects. From the production aspect, the resulting project is no longer oily. Business already has a business license and PIRT sertificate. Product packaging is more attractive, designed according to the packaging standards of the Department of Health. From the marketing aspect, products have been sold at convenience stores and online. Additionally, the sales turnover increased.
\end{abstract}

Keywords_product, design, product packaging, marketing.

\begin{abstract}
Abstrak
Kelompok usaha peyek 3E merupakan usaha industri rumah tangga yang dikelola secara sederhana oleh sekelompok ibu rumah tangga di pusat kota Yogyakarta. Usaha ini dijalankan untuk membantu peningkatan perekonomian keluarga. Rempeyek di produksi secara sederhana di dapur rumah pengelolanya dengan alat - alat produksi seadanya sehingga peyek yang dihasilkan berminyak dan dikemas sederhana. Pemasarannya juga masih terbatas pada warung - warung sekitar. Melalui kegiatan pengabdian ini, kelompok usaha Peyek $3 E$ didampingi untuk meningkatkan mutu produksinya dan memperluas pemasaran. Kegiatan ini melalui 4 tahapan, yaitu persiapan, pelaksanaan, evaluasi dan pelaporan. Hasil dari kegiatan pengabdian dapat dilihat dari aspek produksi dan aspek pemasaran. Dari aspek produksi, peyek yang dihasilkan tidak berminyak lagi. Usaha telah memiliki ijin usaha dan Sertifikat PIRT. Kemasan produk lebih menarik, didesain sesuai dengan standar kemasan dari Dinas Kesehatan. Dari aspek pemasaran, pemasaran diperluas ke pasar modern dan secara online. Omset penjualan setelah kegiatan juga meningkat.
\end{abstract}

Kata kunci-produksi, desain, kemasan, pemasaran

\section{PENDAHULUAN}

Yogyakarta merupakan salah satu daerah tujuan wisata di Indonesia. Wisatawan dapat mengunjungi berbagai objek wisata yang menarik di Yogyakarta. Setiap harinya banyak wisatawan lokal ataupun dari luar negeri yang dating megunjungi Yogyakarta. Yogyakarta akan semakin padat disaat musim liburan. Sektor pariwisata di Yogyakarta tentunya dapat dijadikan sebagai salah satu upaya dalam meningkatkan pendapatan masyarakat(Eri, 2012). Masyarakat Yogyakarta dapat memanfaatkan kondisi ini untuk meningkatkan perekonomiannya dengan memberikan fasilitas yang menarik dan menyenangkan bagi wisatawan. Disamping itu, masyarakat Yogyakarta juga dapat memanfaatkan peluang ini dengan menyediakan berbagai macam oleh - oleh sebagai buah tangan para wisatawan mulai dari kerajinan, batik hingga makanan khas Yogyakarta.

Banyak makanan yang dapat dijadikan oleh-oleh bagi wisatawan yang mengunjungi Yogyakarta. Ada beberapa tips untuk memilih makanan sebagai oleh-oleh yaitu (1) Cek tanggal kadaluwarsa, (2) Lihat kemasan, (3) Pilih rasa sesuai selera dan (4) Perhitungkan barang bawaan(Ulfa, 2018). Rempeyek merupakan salah satu makanan yang dapat dijadikan oleh-oleh 
bagi wisatawan. Rempeyek Yogyakarta memiliki rasa yang khas berbeda dengan rempeyek dari daerah lainnya. Rempeyek adalah makanan yang terbuat dari tepung dengan kacang, udang dan sebagainya, yang kemudian digoreng (Liza Meilida, Jumirah., \& Fitri, 2016). Rempeyek dibuat dalam bentuk pipih. Rempeyek digemari oleh semua kalangan mulai dari anak - anak sampai dewasa. Rempeyek dapat disajikan dengan berbagai variasi seperti menggunakan kacang tanah, udang, teri, dan sebagainya.

Aneka Peyek 3E merupakan usaha industri rumah tangga yang dikelola secara sederhana oleh sekelompok ibu - ibu rumah tangga yang berada di pusat kota Yogyakarta tepatnya di Sidumulyo TR IV/283A RT 20 RW 06 Bener, Tegalrejo, Yogyakarta. Usaha ini dijalankan untuk membantu peningkatan perekonomian keluarga. Keikutsertaan ibu-ibu dalam berusaha dapat meningkatkan kesejahteraan keluarganya(Stevin M E, Femmy C M, \& Selvi M, 2017). Faktanya dalam kehidupan bermasyarakat, kaum ibu sangat berpengaruh dalam mengatur dan mengelola perekonomian keluarga (Khairil \& Dorris, 2019).

Aneka Peyek 3E memproduksi rempeyek dengan kombinasi kacang dan teri atau sesuai dengan pesanan. Rempeyek di produksi secara sederhana di dapur rumah pengelolanya. Alatalat yang digunakan milik pribadi pengelolaya dan masih sangat sederhana. Tabel 1 berikut ini merupakan daftar peralatan produksi yang dimiliki mitra.

Tabel 1. Peralatan Produksi Mitra

\begin{tabular}{lcc}
\hline \multicolumn{1}{c}{ Jenis Peralatan } & Jumlah & Kondisi \\
\hline Panci Penggorengan & 2 & Baik \\
Alat Peniris Minyak Sederhana & 1 & Baik \\
Wadah Pengaduk Adonan & 2 & Baik \\
Kompor Gas & 1 & Baik \\
\hline
\end{tabular}

Rempeyek yang diproduksi di jual ke warung-warung dan angkringan di tempat sekitar. Kemasan rempeyek yang dipasarkan masih sangat sederhana. Rempeyek yang dipasarkan ke warung-warung hanya dikemas dengan plastik biasa dan di alasi dengan kertas bekas, kemudian di setples. Usaha rempeyek ini belum dilengkapi dengan tanggal kadaluarsa apalagi P-IRT. Harga jual perkemasan rempeyek antara Rp. 1.000,00 sampai dengan Rp. 3.000,00. Disamping itu Aneka Peyek 3E juga memproduksi rempeyek sesuai dengan pesanan. Rempeyek yang dipesan dalam jumlah yang cukup besar juga hanya dikemas dalam kantong plastik biasa dan di stepples atau di ikat dengan karet gelang. Gambar 1 berikut ini merupakan contoh produk rempeyek yang dijual ke warung-warung.

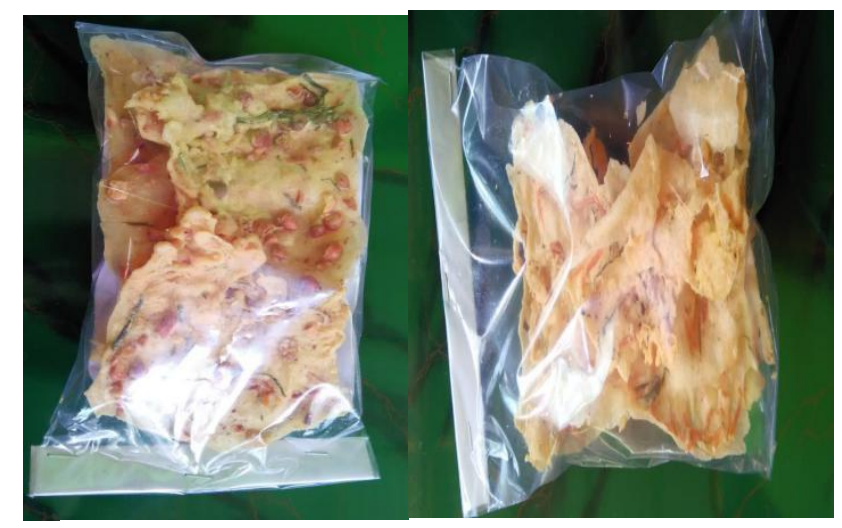

Gambar 1. Rempeyek Kacang dan Teri

Melalui kegiatan ini, tim pengabdi mendampingi mitra dalam memperbaiki proses produksinya sehingga dapat menghasilkan rempeyek dengan kualitas yang lebih baik. Proses produksi merupakan rangkaian kegiatan dalam mengolah bahan dasar menjadi suatu produk yang dapat dijual dengan keuntungan maksimal menggunakan peralatan tertentu(Vicky, Supriyono., Arif Ainur, \& Sugeng Dwi, 2019). Selanjutnya tim pengabdi mendampingi mitra 
dalam memperluas pemasarannya melalui pasar modern karena di Yogyakarta saat ini banyak terdapat pasar-pasar modern yang ramai dikunjugi wisatawan. Disamping itu juga dilakukan pemasaran secara online karena peminat terhadap jual beli online di Indonesia saat ini juga meningkat (Ayu Maulinda, Anggi Aprilia, \& Galang, 2019).

Dari uraian di atas, maka dapat perumusan masalah pada kegiatan pengabdian ini adalah “bagaimana meningkatkan kualitas produksi dan perluasaan pemesaran Peyek 3E?". Adapun tujuan dari kegiatan pengabdian ini adalah untuk meningkatkan kualitas produk Peyek 3E dan memperluas pemasarannya .

\section{METODE}

Ada 4 tahapan yang dilaksanakan dalam Program Kemitraan Masyarakat ini. Tahapan tersebut adalah sebagai berikut :

\section{Tahap Persiapan}

Tahap persiapan meliputi beberapa kegiatan, yaitu :

a. Observasi ke Lokasi Mitra

Observasi langsung ke lokasi mitra yaitu Aneka Peyek 3E bertujuan untuk mengetahui kondisi nyata dari mitra. Kondisi yang diamati mulai dari proses persiapan produksi, proses produksi, pengemasan dan pemasaran.

b. Identifikasi Permasalahan Mitra

Permasalahan mitra diidentifikasi berdasarkan hasil observasi yang telah dilaksanakan secara langsung sebelumnya ke lokasi mitra.

\section{Tahap Pelaksanaan}

Pada tahapan ini, permasalahan mitra yang telah teridentifikasi ditentukan solusinya. Solusi yang ditawarkan telah dirancang oleh ahli sesuai dengan kepakarannya. Solusi yang ditawarkan meliputi aspek produksi dan aspek pemasaran. Solusi yang ditawarkan diharapkan dapat menyelesaikan permasalahan mitra.

\section{Tahap Evaluasi}

Tahap ini untuk mengevalauasi perkembangan usaha mitra setelah diterapkan solusi yang ditawarkan oleh tim pengabdi. Pada tahap ini diukur peningkatan hasil produksi dari sisi kualitasnya dan peningkatan penjualan peyek dari omzet penjualan. Disamping itu juga untuk mengevaluasi proses pelaksanaan Program Kemitraan Masyarakat.

\section{Tahap Pelaporan}

Pada tahapan ini dilaporkan hasil kegiatan dan luaran yang telah dicapai melalui kegiatan pengabdian ini.

Tahapan-tahapan pelaksanaan Program Kemitraan Masyarakat ini dapat dilihat pada gambar 2 berikut : 


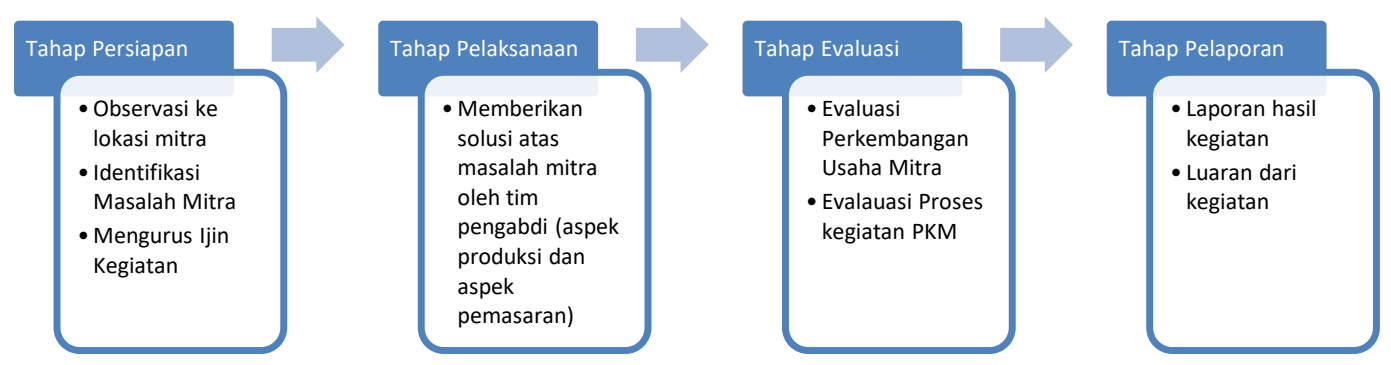

Gambar 2. Tahapan Pelaksanaan PKM

\section{HASIL DAN PEMBAHASAN}

Program Kemitraan Masyarakat pada kelompok usaha peyek 3E memberikan hasil pada setiap tahapan kegiatannya.

\subsection{Tahap Persiapan}

Pada tahap ini dilaksanakan observasi ke lokasi mitra dan wawancara dengan ketua kelompok usaha. Dari hasil observasi dan wawancara dengan mitra ditemukan permasalahan yang dialami oleh mitra sebagai berikut:
a. Mitra belum memiliki ijin usaha
b. Usaha mitra belum memiliki P-IRT
c. Mitra mengalami kendala dalam melakukan proses pengurusan P-IRT karena kondisi tempat produksi usaha yang tidak memenuhi syarat.
d. Mitra masih kekurangan beberapa alat untuk produksi.
e. Peyek yang dihasilkan sangat berminyak karena alat peniris yang digunakan sangat sederhana dan tidak mampu meniriskan minyak secara maksimal.
f. Mitra tidak memiliki kemasan yang memadai untuk dijual lebih luas.
g. Mitra tidak mengerti proses penjualan secara online dan prosedur memperluas penjualan ke toko yang lebih besar (pasar modern).

Permasalahan-permasalahan di atas perlu diatasi agar usaha mitra dapat lebih berkembang lagi. Mengembangkan usaha kecil menengah dalam masyarakat merupakan salah satu upaya penting yang dapat dilakukan untuk meningkatkan kesejahteraan masyarakat(Titik \& Purwaning Budi, 2017). Berdasarkan permasalahan yang ditemui di atas maka solusi yang ditawarkan pengabdi kepada Aneka Peyek 3E sebagai mitra dalam kegiatan pengabdian ini terbagi pada aspek produksi dan pemasaran produk, yaitu :

\section{Aspek Produksi}

Solusi dari aspek produksi yang ditawarkan dalam pengabdian ini adalah sebagai berikut :

a. Menyediakan alat-alat produksi yang sangat penting dalam usaha ini yaitu mesin peniris rempeyek dan alat untuk pengemasan.

b. Membantu pengurusan ijin usaha dan P-IRT sehingga rempeyek dapat dijual lebih luas lagi.

c. Memperbaiki kemasan produk rempeyek.

Kemasan didesain sesuai dengan standar yang telah di tetapkan Dinas Kesehatan.

\section{Aspek Pemasaran}

Peyek berkualitas yang telah dihasilkan dapat memperluas tempat pemasaran. Pasar yang dipilih untuk pemasaran juga harus tepat karena pasar merupakan tempat bertemunya penjual dan pembeli hingga terjadi suatu transaksi(Mahmudah \& Supri 
Wahyudi, 2017). Transaksi yang terjadi dalam pasar tersebut merupakan kegiatan jual beli produk(Kasmir, 2013). Solusi dari permasalahan pemasaran yang ditawarkan dalam Program Kemitraan Masyarakat ini adalah memperluas pemasaran ke pasar modern dan pemasaran secara online.

\subsection{Tahap Pelaksanaan}

Solusi yang ditawarkan pada tahap persiapan baik aspek produksi maupun aspek pemasaran dilaksanakan pada tahap pelaksanaan ini, kegiatan yang dilaksanakan pada tahap ini adalah sebagai berikut :

\section{Aspek Produksi}

a. Meningkatkan kualitas produksi

Mitra mengalami masalah dalam meniriskan minyak sisa penggorengan rempeyek. Terlalu banyak sisa minyak pada rempeyek yang dihasilkan. Oleh sebab itu tim pengabdi mencarikan solusi untuk mitra dengan pengadaan alat pengering (spinner) untuk membantu peningkatan produksi usaha. Tim mitra diberikan pelatihan cara menggunakan spinner agar peyek yang dihasilkan tidak menjadi hancur. Dengan menggunakan spinner, peyek yang dihasilkan tidak berminyak lagi sehingga dapat meningkatkan kualitas dan daya tahan peyek yang dihasilkan juga lebih lama.

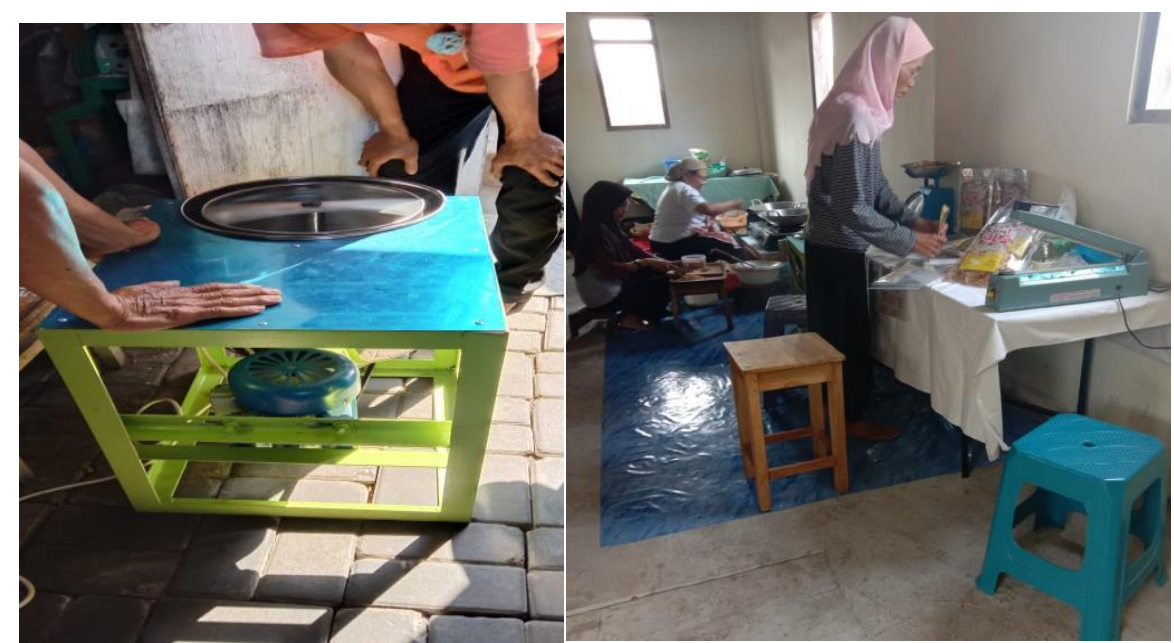

Gambar 3. Proses Produksi

b. Mengurus Sertifikat Industri Rumah Tangga Pangan (P-IRT) dan izin usaha.

Sertifikat Industri Rumah Tangga Pangan (P-IRT) dikeluarkan oleh Dinas Kesehatan Kota Yogyakarta setelah melalui beberapa proses. Tim pengabdi mendampingi mitra untuk mengurus izin usaha dan PIRT. Sebagian besar masyarakt pemilik UKM termasuk mitra merasakan kesulitan dalam mengurus PIRT karena mereka tidak mengerti dengan proses yang harus dilewati padahal sesungguhnya prosesnya sangat mudah dan jelas di Dinas Kesehatan. Tim pengabdi mendampingi mitra dalam setiap proses mendapatkan sertifikat P-IRT. Ada beberapa berkas yang harus dipersiapkan oleh mitra sebagai pengajuan awal yaitu :

1. Mengisi formulir yang telah disediakan

2. Fotokopi Sertifikat Penyuluhan Keamanan Pangan (PKP)

3. Fotokopi Kartu Tanda Penduduk pemilik perusahaan

4. Fotokopi hasil pemeriksaan air atau bukti pembayaran rekening PDAM

5. Denah lokasi industri

6. Denah ruang produksi

7. Rancangan label pangan 
8. Daftar produk yang diajuakan

9. Nomor induk berusaha (Izin Usaha)

Nomor Induk berusaha dapat diperoleh secara online. Tim pengabdi membantu mitra dalam mendapatkan Nomor Induk berusaha secara online. Tim pengabdi juga mendampingi mitra dalam mempersiapkan lokasi produksi dan alat - alat produksi yang sesuai dengan standar kesehatan. Berkas - berkas yang dibutuhkan dipersiapkan dan di serahkan ke Dinas kesehatan Kota Yogyakarta.

Dinas Kesehatan Kota Yogyakarta melakukan visitasi ke lokasi produksi peyek 3E untuk melihat kelayakan tempat produksi dan kelayakan produknya sendiri untuk mendapatkan sertifikat PIRT. Bahan dasar yang digunakan serta proses pengolahan produk juga menjadi sorotan utama dari tim visitasi Dinas Kesehatan. Dari hasil kunjungan tim visitasi Dinas Kesehatan Kota Yogyakarta terdapat beberapa masukan yang harus dipenuhi oleh mitra agar proses pengurusan PIRT dapat dilanjutkan. Masukan dari Dinas Kesehatan tersebut adalah :

1. Kondisi lantai yang masih kasar dan berdebu agar diperhatikan.

2. Peralatan dapur yang terbuat dari palstik dan menggelupas agar segera diganti dengan stainlees stell.

3. Menyediakan sabun cuci tangan dan cuci piring yang berbeda dan juga ada lap kering.

4. Membuat catatan penjualan

5. Segera membuang sampah limbah produksi

Mitra diberikan waktu 10 hari untuk memperbaiki lokasi produksi dan hal - hal lainnya sesuai dengan saran dari tim visitasi Dinas kesehatan Yogyakarta.

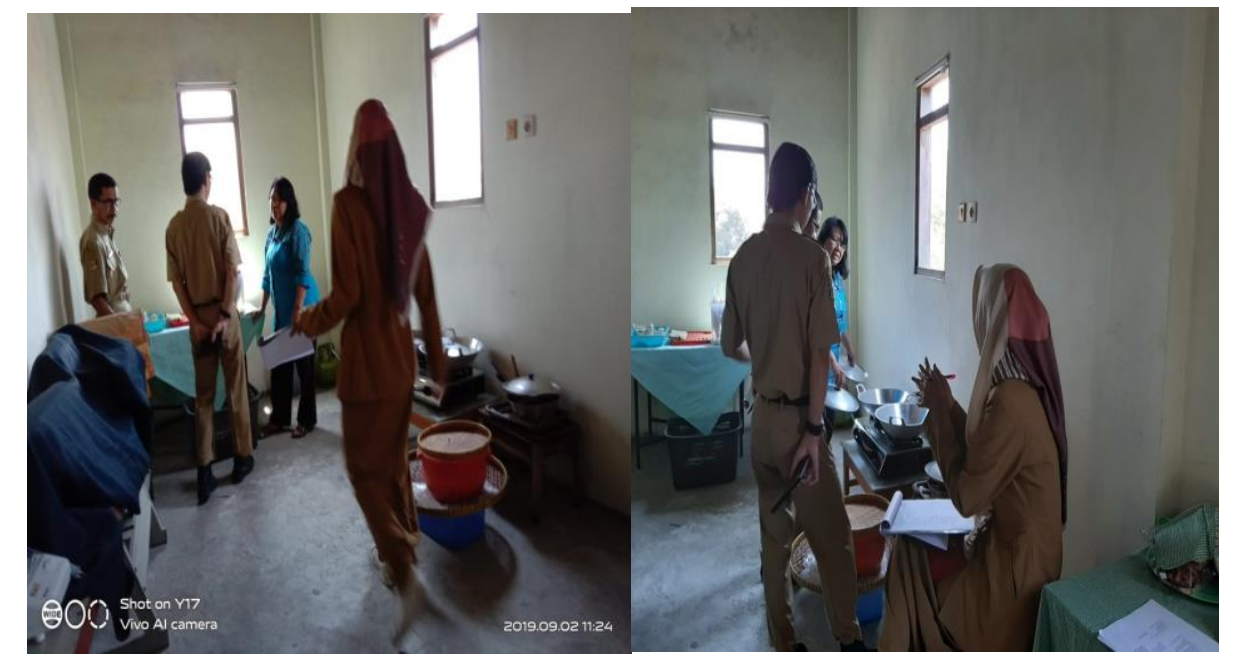

Gambar 4. Kunjungan Dinas Kesehatan untuk Pengurusan PIRT

Tim pengabdi mendampingi mitra untuk melengkapi ataupun memperbaiki sarana dan prasarana proses produksi sesuai dengan saran dari tim visitasi Dinas Kesehatan Yogyakarta. Semua perbaikan yang dilakukan sesuai dengan saran dari tim visitasi Dinas Kesehatan Yogyakarta dilaporkan dan berkas - berkas yang harus dilengkapi diserahkan kembali ke bagian pengurusan PIRT di Dinas Keseshatan Yogyakarta. Setelah melewati semua proses untuk mendapatkan sertifikat P-IRT, akhirnya Peyek 3E berhasil memiliki sertifikat Industri Rumah Tangga Pangan (P-IRT) yang berlaku selama 4 tahun dan siap untuk dikunjungi lagi sewaktu-waktu. 


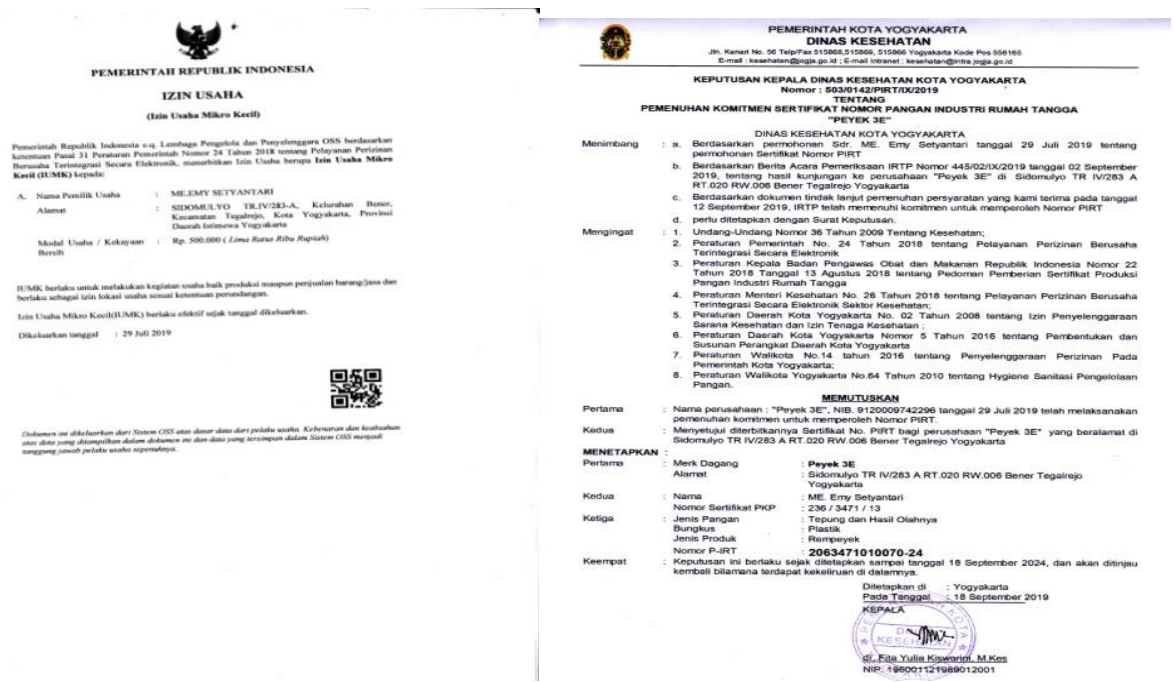

Gambar 5. Sertifikat Izin Usaha dan P-IRT

c. Desain Kemasan

Pada tahapan ini dihasilkan desain kemasan yang lebih baik dari sebelumnya. Kemasan didesain sesuai syarat yang telah ditetapkan oleh Dinas Kesehatan yaitu minimal memuat nama pangan, merk, netto/berat bersih, komposisi, tanggal kadarluasa, kode produksi, nama dan alamat IRTP (minimal kabupaten, Indonesia, kode pos), nomor PIRT, serta tidak mencantumkan klaim kesehatan atau klaim gizi. Kemasan produk didesain sesuai dengan jenis peyek yang diproduksi, yaitu peyek kacang, peyek teri dan peyek kacang hijau. Gambar berikut ini merupakan desain kemasan produk peyek mitra.

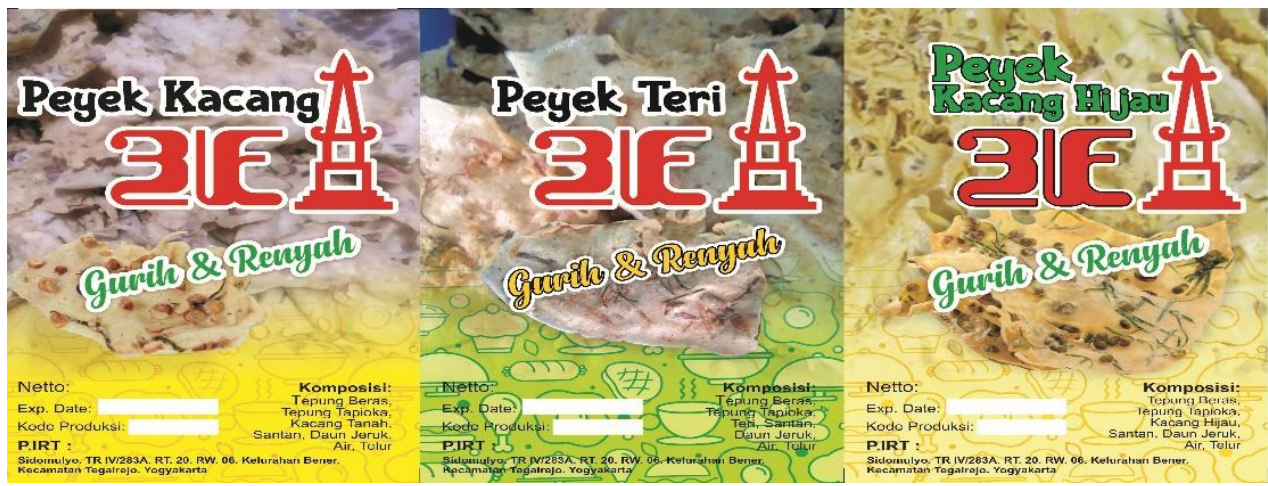

(a)

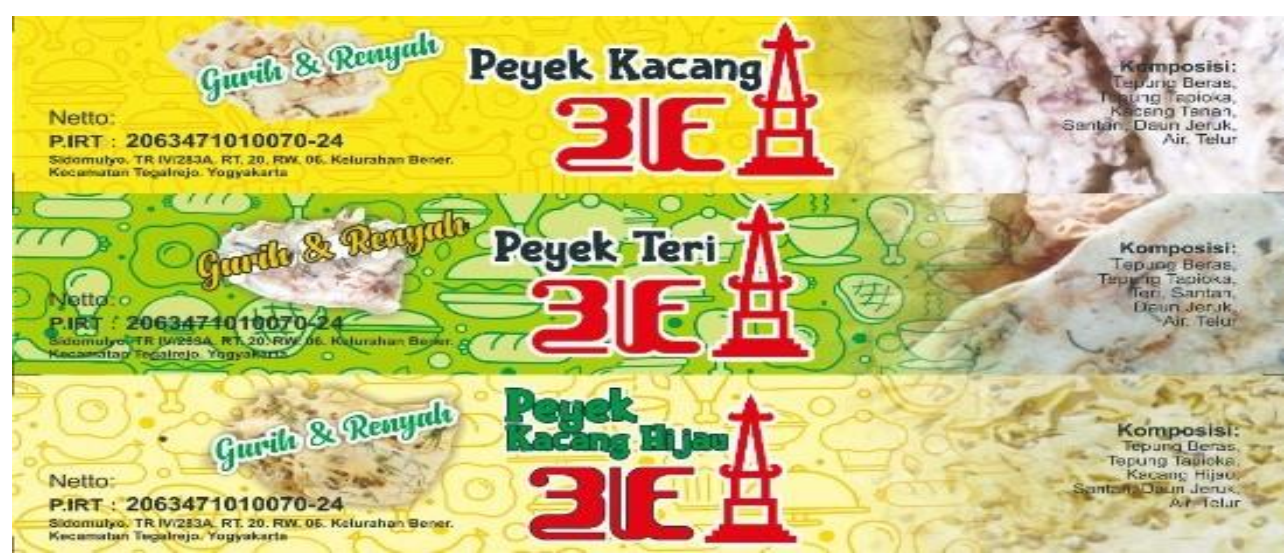

(b)

Gambar 6. Desain Kemasan (a)kemasan 1 ons, (b) kemasan 2 ons 


\section{Aspek Pemasaran}

Pemasaran merupakan serangkaian kegiatan yang dilakukan oleh produsen sebagai upaya menjual produk yang dihasilkan kepada konsumen. Mitra didampingi tim pengabdi mengembangkan pemasaran melalui dua cara pemasaran :

1. Pengembangan pemasaran ke pasar modern

Saat ini banyak konsumen yang memilih berbelanja di pasar modern. Pada pasar modern, penjual dan pembeli tidak bertemu secara langsung. Setiap produk telah dilabeli dengan harga sehingga pembeli dapat melihat langsung harga dari setiap produknya(Annisa Hadif \& Abd, 2018). Pengembangan pemasaran ditargetkan dapat menembus ke toko-toko yang lebih besar (toko modern). Mitra didampingi tim pengabdi melakukan survey ke beberapa toko, minimarket dan supermarket untuk dapat memperluas pemasaran. Toko-toko modern tersebut memiliki beberapa standar produk yang dapat dijual ditokonya. Minimal produk telah memiliki sertifikat PIRT yang dikeluarkan oleh Dinas Kesehatan setempat.

Setelah sertifikat nomor PIRT didapat, tim pengabdi mendampingi mitra dalam upaya memasarkan produknya ke toko-toko modern. Mitra perlu didampingi dalam memperkenalkan produknya ke toko-toko modern karena keterbatasan pengetahuan dan kurangnya pengalaman mitra membuat mitra merasa kurang percaya diri untuk memasarkan produknya ke toko-toko besar. Beberapa minimarket telah menerima produk Peyek 3E untuk dipasarkan disana. Sebagian masih proses penyeleksian oleh toko.

2. Pengembangan pemasaran secara online

Untuk memperluas pemasaran dan menjangkau konsumen lebih banyak lagi dapat dilakukan dengan pemasaran secara online(Himawan, Asep, \& Sugeng, 2014). Kemajuan teknologi dan keaktifan masyarakat dalam menggunakan internet mempengaruhi cara berinteraksi masyarakat saat ini termasuk dalam hal jual beli(Fauyhi Eko, 2016). Website dan media sosial lainnya seperti facebook dan instagram dapat digunakan sebagai tempat promosi dan transaksi jual beli. Tim pengabdi melatih dan mendampingi mitra dalam menggunakan website dan sosial media untuk memasarkan produknya. Mitra memerlukan pelatihan dan pendampingan secara kontinu. Keterbatasan ibu-ibu mitra dalam menggunakan teknologi menyulitkan mitra dalam menjual produk secara online. Mitra terus berlatih untuk menggunakan sosial media untuk berjualan online. Berikut tampilan Instagram, facebook dan website aneka peyek 3E.

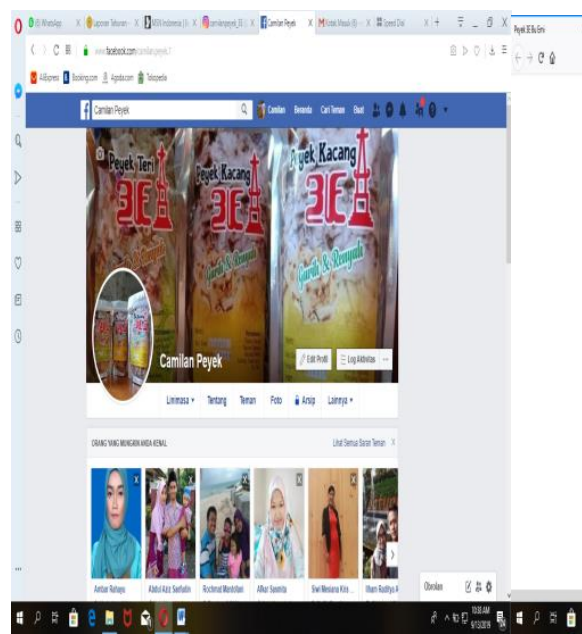

(a)

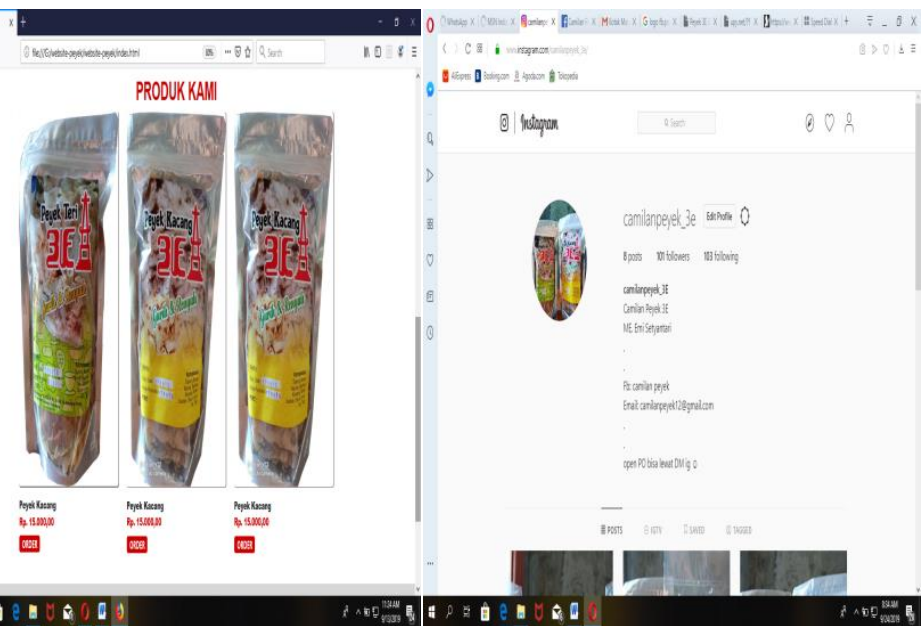

(b) (c)

Gambar 7. Marketing Online(a)facebook (b) website (c)instagram 


\section{3 Tahap Evaluasi}

\section{a. Evaluasi Perkembangan Usaha Mitra}

Pada tahap evaluasi ini diukur keberhasilan program pengabdian yang telah dilaksanakan terhadap usaha mitra. Evaluasi dilakukan terhadap dua aspek, yaitu :

1.) Aspek Produksi

a. Kualitas Peyek.

Aspek produksi dilihat dari kualitas peyek yang di produksi. Peyek yang awalnya diproduksi mengandung minyak saat ini telah bisa lebih kering dan tidak mengandung minyak.

b. Proses Produksi

Kelayakan proses produksi juga telah mendapatkan jaminan dari Dinas Kesehatan Yogyakarta. Pada tanggal 18 September 2019 telah diterbitkan Surat Keputusan Kepala Dinas Kesehatan Kota Yogyakarta Nomor 503/0142/PIRT/IX/2019 tentang Pemenuhan Komitmen Sertifikat Nomor Pangan Industri Rumah Tangga "Peyek 3E”. Dinas Kesehatan Yogyakarta telah menyatakan bahwa Peyek 3E layak dan mendapatkan nomor P-IRT 2063471010070-24 yang berlaku hingga 18 September 2024.

2.) Aspek Pemasaran

Dari segi pemasaran telah mengalami peningkatan penjualan. Tabel berikut ini memberikan rekapan penjualan Peyek 3E untuk rasa kacang, teri dan kacang hijau pada bulan Agustus, September dan Oktober 2019. Untuk data penjualan secara rinci dapat dilihat pada lampiran.

Tabel 2. Rekapan Penjualan Peyek 3E

\begin{tabular}{llccc}
\hline & & \multicolumn{3}{c}{ Jumlah (Kg) } \\
\cline { 3 - 5 } No & Bulan Produksi & Kacang & Teri & $\begin{array}{c}\text { Kacang } \\
\text { Hijau }\end{array}$ \\
\cline { 3 - 5 } 1 & Agustus & 34 & 8.5 & 3 \\
2 & September & 47.4 & 40.75 & 1.5 \\
3 & Oktober & 73 & 46.25 & 3 \\
\hline
\end{tabular}

Jelas terlihat peningkatan penjualan peyek meningkat setiap bulannya. Peyek kacang merupakan jenis peyek yang paling diminati setiap bulannya. Peningkatannya juga sangat signifikan, yaitu meningkat dari penjualan $34 \mathrm{~kg}$ pada bulan Agustus 2019 meningkat menjadi $47.4 \mathrm{~kg}$ pada bulan September 2019. Pada bulan Oktober 2019 meningkat lagi menjadi 73 kg. Peyek teri juga cukup diminati oleh konsumen. Terjadi peningkatan juga untuk penjualan peyek teri. Pada bulan Agustus 2019 peyek teri terjual 8.5 kg. Penjualan peyek teri meningkat sangat tajam pada bulan September 2019 menjadi $40.75 \mathrm{~kg}$. Pada bulan Oktober 2019 mengalami sedikit peningkatan menjadi $46.25 \mathrm{~kg}$. Penjualan peyek kacang hijau tidak mengalami peningkatan. Pada bulan September 2019 malah mengalami penurunan penjualan dari bulan Agustus 2019, yaitu dari $3 \mathrm{~kg}$ menjadi $1.5 \mathrm{~kg}$. Penjualan peyek kacang hijau kembali sama yaitu $3 \mathrm{~kg}$ pada bulan Oktober 2019.

Peningkatan penjualan peyek 3E di atas dapat dilihat lebih jelas dalam grafik 4.1 berikut ini. 
Grafik 1. Peningkatan penjualan Peyek 3E

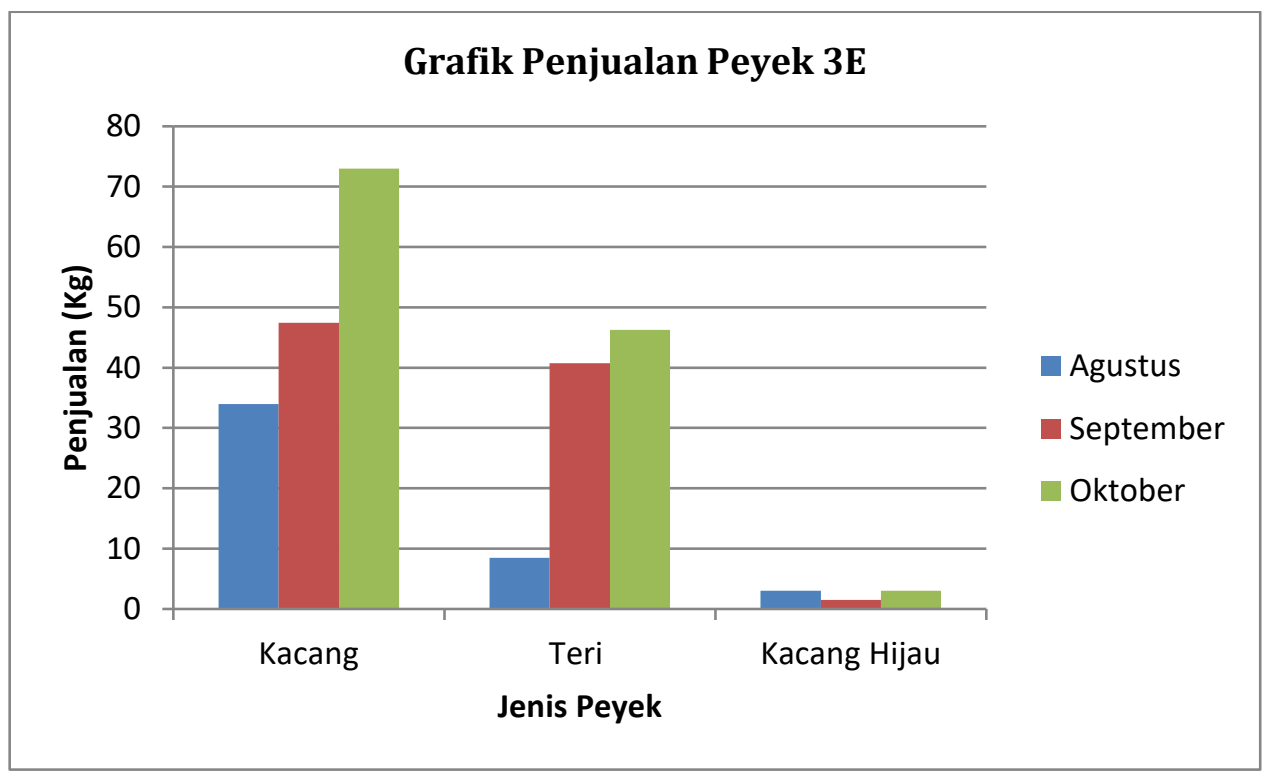

\section{b. Evaluasi Proses Kegiatan Pengabdian}

Setiap tahapan kegiatan pengabdian telah dilaksanakan sesuai dengan rencana awal kegiatan. Output dari kegiatan juga telah sesuai dengan rencana. Berdasarkan wawancara yang dilakukan dengan mitra, kegiatan pengabdian ini juga telah memberikan manfaat yang besar bagi mitra. Hal ini terbukti dengan pemasaran yang semakin luas dan peningkatan omset penjualan setiap harinya.

Ada beberapa hal yang menjadi kendala dalam pelaksanaan kegiatan pengabdian ini, yaitu :

1. Susahnya mencari waktu yang pas untuk melatih mitra pemasaran online.

2. Kondisi mitra yang merupakan ibu-ibu rumah tangga yang tidak akrab dengan teknologi membutuhkan waktu yang cukup lama untuk melatih kemampuan mitra menggunakan website dan media sosial.

3. Kurangnya kepercayaan diri mitra untuk memperluas produknya ke pasar-pasar modern.

4. Proses pembuatan sertfikat P-IRT memerlukan waktu yang cukup lama karena antrian pemohon di Dinas Kesehatan Yogyakarta yang cukup banyak sehingga membuat proses pemasaran juga terlambat.

\subsection{Tahap Pelaporan}

Pada tahapan ini, dilaporkan semua proses rangkaian kegiatan pengabdian dan output dari kegiatan ini. Luaran yang telah diperoleh juga dilaporkan pada tahapan ini. Luaran yang telah diperoleh adalah artikel, poster kegiatan, modul, website dan brosur promosi.

\section{KESIMPULAN}

a. Kualitas produksi peyek telah meningkat. Peyek tidak lagi mengandung minyak yang banyak.

b. Desain kemasan telah di sesuaikan dengan standar minimal dari Dinas Kesehatan Yogyakarta, yaitu mencantumkan nama pangan, merk, netto/berat bersih, komposisi, tanggal kadarluasa, kode produksi, nama dan alamat IRTP (minimal kabupaten, 
Indonesia, kode pos), nomor PIRT, serta tidak mencantumkan klaim kesehatan atau klaim gizi.

c. Perluasan pemasaran ke supermarket dan melalui media online dapat meningkatkan penjualan namun mitra sedikit mendapatkan kesulitan dalam menggunakan media online.

\section{UCAPAN TERIMA KASIH}

Penulis mengucapkan terima kasih kepada Kementrian Riset, Teknologi dan Pendidikan Tinggi yang telah memberi dukungan finansial terhadap pengabdian ini melalui Program Kemitraan Masyarakat. Penulis juga mengucapkan terima kasih kepada Universitas PGRI Yogyakarta melalui LPPM yang telah memberikan dukungan dan bimbingan kepada tim pengabdi. Terima kasih yang sebesar-besarnya kepada semua pihak yang telah memberikan kelancaran kegiatan pengabdian ini.

\section{DAFTAR PUSTAKA}

Annisa Hadif, N., \& Abd, J. (2018). Dampak Pasar Modern (Alfamart) Terhadap Usaha Pasar Tradisional Di Kabupaten Aceh Besar. Jurnal Ilmiah Mahasiswa (JIM), 3(1), 59-67.

Ayu Maulinda, W., Anggi Aprilia, P., \& Galang, B. (2019). Pelatihan Digital Marketing Strategy Untuk Mencapai Kemandirian Masyarakat. DINAMISIA. Jurnal Pengabdian Kepada Masyarakat, 3(1), 147-157.

Eri, B. (2012). Potensi Wisata Kuliner Dalam Mendukung Pariwisata Di Kota Padang. Jurnal Riset Akuntansi Dan Bisnis, 12, 74-101. Retrieved from http://jurnal.umsu.ac.id/index.php/akuntan/article/downloadSuppFile/402/26

Fauyhi Eko, N. (2016). Perancangan Sistem Informasi Penjualan Online Studi Kasus Tokoku. Simetris: Jurnal Teknik Mesin, Elektro Dan Ilmu Komputer, 7(2), 717. https://doi.org/10.24176/simet.v7i2.786

Himawan, Asep, S., \& Sugeng, S. (2014). Analisa dan Perancangan Sistem Informasi Penjualan Online (E-Commerce) Pada CV Selaras Batik Menggunakan Analisa Deskriptif. Scientific Journal Of Informatics, 1(1), 53-63.

Kasmir. (2013). kewiraushaan (Revisi). Jakarta: PT. Raja Grafindo Persada.

Khairil, H., \& Dorris, Y. (2019). Pengembangan Usaha Kuliner Home Industri Sebagai Peluang Kaum Perempuan Menuju Industri Kreatif. DINAMISIA. Jurnal Pengabdian Kepada Masyarakat, 3(special issue), 110-116.

Liza Meilida, N., Jumirah., \& Fitri, A. (2016). Uji Daya Terima Rempeyek Kacang Hijau Yang Dimodifikasi Dengan Tepung Belalang Kayu (Melanoplus Cinereus). Jurnal Gizi, Kesehatan Reproduksi Dan Epidemiologi, 1(02).

Mahmudah, M., \& Supri Wahyudi, U. (2017). Analisis Dampak Keberadaan Pasar Modern Terhadap Pasar Tradisional Sleko di Kota Madiun. Assets: Jurnal Akuntansi Dan Pendidikan, 6(1), 59-72. https://doi.org/10.25273/jap.v6i1.1293

Stevin M E, T., Femmy C M, T., \& Selvi M, T. (2017). Peran Ganda Ibu Rumah Tangga Dalam Meningkatkan Kesejahteraan Keluarga Di Desa Allude Kecamatan Kolongan Kabupaten Talaud. Acta Diurna, VI(2), 2.

Titik, W., \& Purwaning Budi, L. (2017). IbM-PENDAMPINGAN USAHA KERUPUK RUMAHAN DI DESA KEMBANG KABUPATEN PACITAN. Jurnal ABDIMAS Unmer Malang, 2(01), 20-25.

Ulfa, I. (2018). Tips Memilih Makanan Sebagai Oleh - Oleh. Koran Sindo. GEN SINDO Universitas Indonesia. Retrieved from http://lifesstyle.sindonews.com/read/1273301/185/tipsmemilih-makanan-sebagai-oleh-oleh-1515810879

Vicky, P., Supriyono., Arif Ainur, R., \& Sugeng Dwi, R. (2019). Peningkatan Proses Produksi Pada UMKM Makanan Di Desa Maos Lor, Kecamatan Maos, Kabupaten Cilacap. Jurnal Berdaya Mandiri, 1(1), 25-34. 